\title{
Effect of Per Os Administration of Mercuric Chloride on Peroxidation Processes in Japanese Quail
}

\section{Š. FAIX ${ }^{1}$, Z. FAIXOVÁ ${ }^{2}$, E. MICHNOVÁ ${ }^{2}$, J. VÁRADY ${ }^{3}$}

${ }^{1}$ Institute of Animal Physiology, Slovak Academy of Sciences, Košice, ${ }^{2}$ Department of Pathological Anatomy, Physiology and Genetics, Section of Pathological Physiology, University of Veterinary Medicine, Košice, ${ }^{3}$ Department of Normal Anatomy, Histology and Physiology, Section of Comparative Physiology, University of Veterinary Medicine, Košice, Slovak Republic

Received June 10, 2002

Accepted March 25, 2003

\section{Abstract}

Faix, Š., Z. Faixová, E. Michnová, J. Várady: Effect of Per Os Administration of Mercuric Chloride on Peroxidation Processes in Japanese Quail. Acta Vet. Brno 2003, 72: 23-26

Activities of glucose-6-phosphate dehydrogenase (G-6-PD, E.C. 1.1.1.49), superoxide dismutase (SOD, E.C. 1.15.1.1) in erythrocytes and the amount of malondialdehyde (MDA) precursors in the liver and kidney were examined in Japanese quails exposed to mercuric chloride $\left(\mathrm{HgCl}_{2}\right)\left(25 \mathrm{mg} . \mathrm{l}^{-1}\right.$ drinking water) for 60 days. Lipid peroxidation was determined by the thiobarbituric acid reaction measuring the production of malondialdehyde precursors and the enzymes activities were measured by the spectrophotometric methods. Lipid peroxidation measured by the quantification of MDA precursors was significantly higher in both quail organs treated with $\mathrm{HgCl}_{2}$ than in control groups (liver: $5.3 \pm 0.22$ in the controls vs. $16.0 \pm 0.62 \mu \mathrm{mol}^{-1}, P<0.001$; kidney: $7.6 \pm 0.21$ in the controls vs. $\left.19.0 \pm 0.61 \mu \mathrm{mol} . \mathrm{g}^{-1}, P<0.001\right)$. The activities of both SOD and G-6-PD in erythrocytes after the administration of $\mathrm{HgCl}_{2}$ were significantly less than in the control group (G-6-PD: $59.98 \pm 1.22$ in the controls vs. $41.5 \pm 3.19 \mathrm{mU} .10^{-9} \mathrm{Ec}, P<0.001$; SOD: $1361 \pm 48.37$ in the controls vs. $1034 \pm$

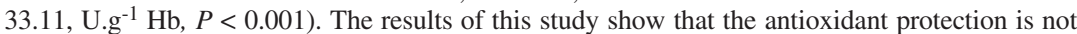
supported by glucose-6-phosphate dehydrogenase and superoxide dismutase.

Antioxidant protection, lipid peroxidation, Japanese quails, mercury chloride

One of the harmful effects of mercury action during its accumulation in a body in a region contaminated by mercury is the excessive release of reactive oxygen species and increased lipid peroxidation in the cells (Lund et al. 1993). Free radicals and intermediate products of peroxidation are capable of damaging the integrity and altering the function of biomembranes, which can lead to the development of many pathological processes (Gutteridge 1993). Various specific enzymes that limit free-radical formation, such as superoxide dismutase (SOD) and glucose-6-phosphate dehydrogenase (G-6-PD), play an important role in the protection of cell membranes against oxidative damage. Protective systems existing in the cells avoid the excessive increment of undesirable oxidizers. Three enzymes form the corner stone of this protection: superoxide dismutase, catalase and glutathione peroxidase. Glucose-6phosphate dehydrogenase is the key enzyme, catalyzing the first step of pentose phosphate metabolic pathway. The pentose phosphate metabolic pathway is a unique source of NADPH in erythrocyte and synthesis of NADPH decreases in G-6-PD deficiency. One of major roles of NADPH in erythrocyte is detoxication of hydrogen peroxide and oxygen radicals in and on the red blood cells (Deutsch 1983). There is conflicting evidence about the effect of oxidative damage on the activities of these antioxidant-associated enzymes. The aim of this work was to study the effect of administration of mercuric chloride on SOD and G-6-PD activities in erythrocytes as well as on lipid peroxidation in the liver and the kidney of Japanese quails.

Address for correspondence:

MVDr. Štefan Faix, PhD.

Institute of Animal Physiology

Šoltésovej 4, 04001 Košice, Slovak Republic
Phone: +421556332048

Fax: +421 55728784

http://www.vfu.cz/acta-vet/actavet.htm 


\section{Materials and Methods}

Animals

The experiments were carried out on twelve Japanese quails, weighing from 115 to 125 grams, 9 weeks of age. The birds were fed a standard diet for chickens (a complete pelleted feed mixture for poultry of all age groups). The quail were divided into two groups. The experimental group $(\mathrm{n}=6)$ was treated with mercuric chloride $\left(\mathrm{HgCl}_{2}\right)$. Mercuric chloride was added to their drinking water at a concentration of $25 \mathrm{mg} \cdot \mathrm{l}^{-1}$ for 60 days before the measurement of enzymes activities. The control group received untreated drinking water for the same period. Water was supplied ad libitum. After 60 days exposure to mercuric chloride, the birds were quickly killed by cervical decapitation and exsanguination. At all times, the quails received care in compliance with international accepted procedures. Blood samples were collected after decapitation into heparinized tubes and the liver and kidney were dissected.

The activities of the superoxide dismutase, glucose-6-phosphate dehydrogenase in the erythrocytes and amount of malondialdehyde precursors in the liver and kidney tissue were measured by spectrophotometric methods on SPEKOL 11 (Carl Zeiss Jena).

Superoxide Dismutase

The activity of superoxide dismutase in blood was measured by the comercial kit (RANDOX Laboratories Ltd., UK). This method uses xanthine and xanthine oxidase to generate superoxide radicals which react with 2-(4iodophenyl)-3-(4-nitrophenol)-5-phenyltetrazolium chloride to form a red formazan dye.

Glucose-6-phosphate Dehydrogenase

The activity of glucose-6-phosphate dehydrogenase in blood was measured by the comercial kit (RANDOX Laboratories Ltd., UK). The enzyme activity is determined by measurement of the rate of absorbance change at 340 $\mathrm{nm}$ due to the reduction of $\mathrm{NADP}^{+}$.

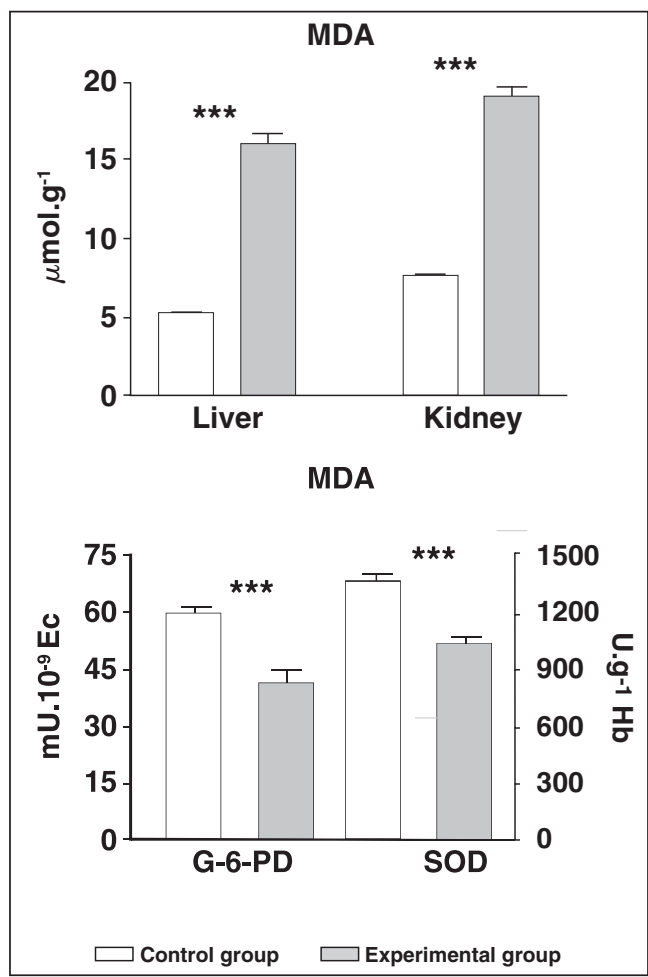

Fig. 1. The levels of malondialdehyde (MDA) in liver and kidney tissue; the activities of glucose-6-phospate dehydrogenase (G-6-PD) and superoxide dismutase (SOD) in the blood of the Japanese quails after 60 days action of the mercuric chloride. Values are means \pm S.E.M., $n=6$ for each group. Significance: $* * *=P<0.001$.
Lipid Peroxidation

The lipid peroxidation was determined by the thiobarbituric acid reaction measuring the production of malondialdehyde (MDA) precursors in the liver and kidney tissue by the method of Mihara and Uchiy ama (1978).

Statistical analysis

The results are given as means \pm S.E.M. Statistical analyses of the differences between the control and $\mathrm{HgCl}_{2}$-treated group were performed by the Student's $t$-test according to Snedecor and Cochran (1967).

\section{Results and Discussion}

The treatment of Japanese quails with mercuric chloride had effects on the activities of the antioxidative enzymes in the blood and on lipid peroxidation in the liver and kidney tissue (Fig. 1). Our results show that lipid peroxidation was significantly higher in both liver and kidney tissue in the experimental group compared with the control group (liver: $16.0 \pm 0.62$ to $5.3 \pm 0.22$ umol.g ${ }^{-1}, P<0.001$; kidney: $19.0 \pm 0.61$ to $7.6 \pm 0.21 \mu$ mol.g $\left.{ }^{-1}, P<0.001\right)$. The experimental work confirms that $\mathrm{Hg}$ ions initiate and stimulate peroxidative reactions both in vitro and in vivo by a direct effect on the cell membrane with a consequent increase in the release of reactive oxygen species as well as with the inactivation of the body's antioxidants (Andersen and Andersen 1993; Lund et al. 1993). 
Huang et al. (1996) have shown that the parenteral administration of mercuric chloride to rats enhances lipid peroxidation in the liver, kidney, lung, testis, and serum, but not in the heart, spleen or muscle. After the subcutaneous injection of mercuric chloride, MDA concentrations in the liver and kidney significantly increased after 9 hours and reached peak values at 24 hours. The intramuscular injection of mercuric chloride enhances lipid peroxidation in the cerebral cortex, cerebellum and sciatic nerves in rats (Anuradha and Varalakshmi 1999).

The activities of G-6-PD and SOD in the blood was significantly lower (G-6-PD: 59.98 \pm 1.22 in the controls vs. $41.5 \pm 3.19 \mathrm{mU} \cdot 10^{-9} \mathrm{Ec}, P<0.001$; SOD: $1361 \pm 48.37$ in the controls vs. $1034 \pm 33.11$ U.g $^{-1} \mathrm{Hb}, P<0.001$ ) after 60 days of mercury chloride administration. These lower activities apparently related to the binding of $\mathrm{Hg}$ on sulfhydryl groups of enzymes. Our results extend information about the effect of metal ions on the activities of antioxidant-associated enzymes.

The oxidative load induced by cadmium in rats (Manca et al. 1991), nickel in mice (Dieter et al. 1988) and aluminium in rats (Zaman et al. 1993) also decreases the activities of G-6-PD and SOD. The higher activity of G-6-PD in sheep after an 8-day administration of $\mathrm{Hg}$ (Košto vá et al. 1995) and during a 3-day application of $\mathrm{Pb}$ (Hacker et al. 1990) in rats is probably a compensatory mechanism to counter of excessive peroxidation in the initial phase of the oxidative load.

Our results show that only the long-term administration of mercury decreases the activity of SOD and G-6-PD, which corresponds with the results of Bulat et al. (1998), who measured the lower activities of SOD in the erythrocytes of workers occupationally exposed to mercury. Moreover, Zabinsky et al. (2000) have shown that the long-term exposure of man to mercury vapours significantly decreases the activities of G-6-PD and SOD.

In conclusion, lipid peroxidation, determined as malondialdehyde production is higher in the liver and kidney tissue of Japanese quails after a prolonged exposure to mercury in drinking water. The results of this study show that the antioxidant protection is not supported by glucose-6-phosphate dehydrogenase and superoxide dismutase.

\section{Vplyv orálne podávaného chloridu ortutnatého na peroxidatívne procesy u japonských prepelíc}

Aktivity glukózo-6-fosfát dehydrogenázy (G-6-PD, E.C. 1.1.1.49), superoxid dizmutázy (SOD, E.C. 1.15.1.1) v erytrocytoch a množstvo malondialdehydových (MDA) prekurzorov v pečeni a obličkách boli merané u japonských prepelíc vystavených účinkom chloridu ortutnatého $\left(\mathrm{HgCl}_{2}\right)$ v dávke $\left(25 \mathrm{mg} \cdot \mathrm{l}^{-1}\right.$ pitnej vody) po dobu 60 dní. Peroxidácia lipidov, ktorá bola meraná reakciou kyseliny tiobarbiturovej na produkciu malondialdehydových prekurzorov a aktivity enzýmov boli merané spektrofotometrickými metódami. Peroxidácia lipidov meraná hladinou MDA prekurzorov bola signifikantne vyššia v oboch orgánoch prepelíc ovplyvnených $\mathrm{HgCl}_{2}$ oproti kontrolnej skupine (pečeň: kontrolná skupina $5.3 \pm$ $0.22, \mathrm{HgCl}_{2}$ skupina $16.0 \pm 0.62 \mu \mathrm{mol} . \mathrm{g}^{-1}, \mathrm{P}<0.001$; obličky: kontrolná skupina $7.6 \pm 0.21$, $\mathrm{HgCl}_{2}$ skupina $\left.19.0 \pm 0.61 \mu \mathrm{mol} . \mathrm{g}^{-1}, P<0.001\right)$. Aktivity SOD a G-6-PD v erytrocytoch po podávaní $\mathrm{HgCl}_{2}$ boli signifikantne nižšie než v kontrolnej skupine (G-6-PD: kontrolná skupina $59.98 \pm 1.22, \mathrm{HgCl}_{2}$ skupina $41.5 \pm 3.19 \mathrm{mU} .10^{-9} \mathrm{Ec}, P<0.001$; SOD: kontrolná skupina $1361 \pm 48.37, \mathrm{HgCl}_{2}$ skupina $1034 \pm 33.11$ U.g $\left.^{-1} \mathrm{Hb}, P<0.001\right)$. Výsledky tejto práce ukazujú, že antioxidačná ochrana japonských prepelíc nie je podporovaná glukózo-6fosfát dehydrogenázou a superoxid dizmutázou.

Acknowledgements

This study was supported by grant No. 1/5146/98 awarded by the Grant Agency for Science VEGA of the Slovak Republic. 


\section{References}

ANDERSEN, HR, ANDERSEN, O 1993: Effects of dietary alpha-tocopherol and beta-carotene on lipid peroxidation induced by methyl mercuric chloride in mice. Pharmacol Toxicol 73: 192-201

ANURADHA, B, VARALAKSHMI, P 1999: Protective role of DL-alpha-lipoic acid against mercury-induced neural lipid peroxidation. Pharmacol Res 39: 67-80

BULAT, P, DUJIC, I, POTKONJAK, B, VIDAKOVIC, A 1998: Activity of glutathione peroxidase and superoxide dismutase in workers occupationally exposed to mercury. Int Arch Occup Environ.Health 71: S37-S39

DEUTSCH, J 1983: Glucose-6-phosphate dehydrogenase. In: Bergmeyer, HU, Bergmeyer, J (Eds), Methods of enzymatic analysis, vol 3. Verlagsgesellschaft: VCH, 190-196

DIETER, MP, JAMESON, CW, TUCKER, AN, LUSTER, MI, FRENCH, JE, HONG, HL, BOORMAN, GA 1988: Evaluation of tissue disposition, myelopoietic, and immunologic responses in mice after long-term exposure to nickel sulfate in the drinking water. J Toxicol Environ Health 24: 357-372

GUTTERIDGE, JM 1993: Free radicals in disease processes: a compilation of cause and consequence. Free Radic Res Commun 19: 141-158

HACKER, HJ, BANNASCH, P, COLUMBANO, A 1990: Effect of lead nitrate on liver carbohydrate enzymes and glycogen content in the rat. Carcinogenesis 11: 2199-2204

HUANG, YL, CHENG, SL, LIN, TH 1996: Lipid peroxidation in rats administrated with mercuric chloride. Biol Trace Elem Res 52: 193-206

KOŠŤOVÁ, D, MICHNOVÁ, E, LEGÁT, J, KRUPICER, I 1995: Intoxication by heavy metals in relation to the activity of glucose-6-phosphate dehydrogenase of erythrocytes in sheep. Vet Med - Czech 40: 371-375

LUND, BO, MILLER, DM, WOODS, JS 1993: Studies on Hg (II)-induced $\mathrm{H}_{2} \mathrm{O}_{2}$ formation and oxidative stress in vivo and in vitro in rat kidney mitochondria. Biochem Pharmacol 45: 2017-2024

MANCA, D, RICARD, AC, TROTTIER, B, CHEVALIER, G 1991: Studies on lipid peroxidation in rat tissues following administration of low and moderate doses of cadmium chloride. Toxicology 67: 303-323

MIHARA, M, UCHIYAMA, M 1978: Determination of malonaldehyde precursors in tissues by thiobarbituric acid test. Anal Biochem 86: 271-278

SNEDECOR, GW, COCHRAN, WG 1967: Statistical methods. Iowa State University Press, Ames, IA

ZABINSKY, Z, DABROWSKY, Z, MOSZCZYNSKI, P, RUTOWSKI, J 2000: The activity of erythrocyte enzymes and basic indices of peripheral blood erythrocytes from workers chronically exposed to mercury vapours. Toxicol . Ind . Health 16: 58-64

ZAMAN, K, ZAMAN, W, SIDDIQUE, H 1993: Hematological and enzymatic results of aluminium intoxication in rats. Comp Biochem Physiol C105:73-76 